\title{
Dental pulp pain in young and postmenopausal women: a pilot study
}

\author{
Jelena Krunić', Irena Mladenović2, Nikola Stojanović \\ 'University of East Sarajevo, Faculty of Medicine, Department of Restorative Dentistry and Endodontics, Foča, Republika \\ Srpska, Bosnia and Herzegovina; \\ ${ }^{2}$ University of East Sarajevo, Faculty of Medicine, Department of Oral Rehabilitation, Foča, Republika Srpska, Bosnia and \\ Herzegovina
}

\begin{abstract}
SUMMARY
Introduction This pilot study was aimed to compare pulpal pain provoked by electrical and thermal (cold) stimuli in healthy young women during various phases of menstrual cycle and postmenopausal women.

Material and methods The study included 20 regularly menstruating healthy women and 20 postmenopausal women. Electrical (electrical pulp tester) and cold (refrigerant spray) stimuli were performed on mandibular central incisors, twice in regularly menstruating (menstrual and luteal phases) and once in postmenopausal women. Results were expressed as pain threshold values for electrical pulp stimulation (0-80 units) and pain intensity scores (visual numeric scale, from 0 to 10 ) for cold stimulation.

Results In young women, higher pain electrical threshold $(p=0.484)$ and pain sensitivity score $(p=0.015)$ were observed in luteal in comparison to menstrual phase. In postmenopausal women, electrical pain threshold was significantly higher while pain intensity score was significantly lower than in young women, regardless of the menstrual phase and painful stimuli.
\end{abstract}

Conclusion Lower responsiveness to dental pulp pain was obtained in young women in luteal phase and postmenopausal women.

Keywords: dental pulp; menstrual cycle; pain; menopause

\section{INTRODUCTION}

A large number of clinical and experimental studies on sex differences in various painful conditions have shown their higher prevalence in women $[1,2]$. Migraine headache, tension-type headache, fibromyalgia, rheumatoid arthritis, osteoarthritis, irritable bowel syndrome, and temporomandibular disorders (TMD) are more common in women than in man [1,3-8]. Furthermore, women experience higher pain intensity, pain frequency and longer duration of pain $[1,9]$. Women are also more likely to consult physicians because of various pain conditions [1]. Sex differences in pain response can be ascribed to social, neurophysiological, genetic, and immunological influences, as well as to the effects of gonadal hormones. A large number of findings suggest gonadal hormones may affect pain perception in women $[1,10]$. In the lifetime hormonal levels modulate significant changes in clinical pain conditions in women. Namely, TMD and migraine headache usually appear after puberty and peak during the reproductive period, in the 20-45-age range [10]. Pain intensity in TMD, migraine headache, and other painful clinical conditions increases towards the end of the menstrual cycle and during the first days of menstruation $[11,12]$. These findings suggest that decrease in estrogen and progesterone levels during perimenstrual phase cause onset and increase of pain. Hormonal milieu during early luteal phase (decrease in estrogen concentration with rise in progesterone concentration) has also been related to increased migraine pain intensity. Similarly, TMD pain level can increase during ovulation, the phase characterized by the rapid change in estrogen level [11]. Conversely, pain fluctuation during menstrual cycle has not been observed in patients with fibromyalgia [12].

Changes in pain conditions could be expected after the reproductive period due to both ageing process and other medical causes. Studies have shown that in postmenopausal period the prevalence of TMD and migrenous headaches decreases [10], but prevalence of other pain syndromes such as fibromyalgia and osteoarthritis increases $[10,13]$. These findings suggest that changes in pain conditions in postmenopausal period depend on the pain modality and characteristics [14]. Unlike clinical pain conditions, it is not yet clear if pain sensitivity on various acute stimuli in healthy women (experimental pain) depends on hormonal status. Namely, several authors have indicated increased pain sensitivity on various stimuli in healthy women during various menstrual phases $[15,16]$, while others have shown an absence in pain response variability during menstrual cycle [17, 18]. Hormones affect numerous sites for pain sensitivity modulation: primary afferent fibres, spinal cord, brainstem, and cerebrum [19]. As gonadal hormone receptors have been identified throughout the nervous system [20] 
it is possible that these hormones affect numerous sites to modulate pain. It has been demonstrated that gonadal hormones interact with nociceptive processes at multiple levels of the peripheral and central nervous system [12, 21]. However, the exact role of gonadal hormones in nociceptive modulation is rather complex and yet not fully understood [22].

Fluctuation in ovarian hormones during menstrual cycle and in various life periods may affect physiological and pathological responses of dental pulp. Namely, estrogen receptors have been detected in the pulp tissue in women in reproductive age, as well as in menopausal women, regardless of age [23]. Also, it has been proven that lower estrogen level during menstrual phase in regularly menstruating and menopausal women is related to lower pulp blood flow [24]. However, according to Tófoli et al. [25], who investigated anaesthetic efficacy and pain induced by dental anaesthesia in regards to menstrual phase, no association between menstrual cycle and investigated parameters of dental anaesthesia has been found, both in healthy regularly menstruating women and women using contraceptives. The influence of hormonal changes during menstrual cycle and postmenopausal period on the pulp pain sensitivity has not yet been investigated. Better insight into these interactions might be of great importance to improve the treatment efficacy.

The aim of this pilot study was to compare the pulp pain response provoked by electrical and thermal (cold) stimuli in young healthy women during various phases of menstrual cycle and postmenopausal women.

\section{MATERIAL AND METHODS}

Forty healthy and pain-free women were selected from patients attending yearly routine check-ups, or subjects accompanying the patients referred to the Specialist Clinic of Faculty of Medicine, University of East Sarajevo, Republic of Srpska, Bosnia and Herzegovina. The subjects were divided into the two groups: the group of regularly menstruating women (menstrual cycle defined as varying between 26 and 28 days), aged 20 to 40 years (mean age 32.8 \pm 5.9 ) $(\mathrm{nS}=20)$, and the group of postmenopausal women (at least 2 years after menopause), aged 50 to 65 years (mean age $59.6 \pm 4.4)(\mathrm{n}=20)$. The inclusion criteria were: the presence of vital mandibular central incisor free of caries, restorations, crowns or veneers and tooth wear, without pulp and periodontal disease. Further criteria were no known medical condition, pregnancy, intake of oral contraceptives, any drugs on a regular basis or any medications that could alter pain perception for at least 24 hours proceeding each test session. Furthermore, there was no recent history of orthodontic treatment, periodontal treatment or trauma. Only one tooth per patient was included.

Each regularly menstruating woman was tested twice, once during the menstrual phase (1-5 days of menstrual cycle) and once during the luteal phase (days 17-23). Postmenopausal women were tested once. Dental pulp sensitivity was tested by electrical and thermal (cold) stimuli. Before test the tooth surface was isolated and dried by cotton rolls. The electric test was done using digital pulp tester (Analytical Technologies, Redmond, WA) with reads from 0-80 units. As a conducting medium, toothpaste was applied lightly to the electrode. The probe was placed on the incisal third of the buccal surface. Participants were asked to raise their hand on first detection of painful sensation. The lowest current intensity that provoked pulp response was considered as pain threshold.

Cold pulpal testing was done by a refrigerant spray (Endo-Frost -50C; Coltene/Whaledent, Altstatten, Switzerland), applied to the incisal third of the buccal surface of the tooth using a cotton pellet for 15 seconds, or until participant indicated a response. Participant was asked to rate her pain on a 0 to 10 numeric rating scale (NRS), with 0 representing no pain and 10 indicating the worst pain the subject has ever experienced. The test was repeated once if there was no response. A 0 value was marked if no response was obtained. A recovery period of at least 2 minutes was allowed after each pulp test.

Data were analyzed using SPSS 19.0 (SPSS, IBM Corp., Armonk, NY). The means and SDs for parametric data, and frequencies for nonparametric data were calculated. To compare pain sensitivity induced by electrical stimulus between the various phases of menstrual cycle and between the two groups of participants Student's t-test for unpaired sample and independent t-test were used, respectively. To compare difference in prevalence and intensity of pain induced by cold stimulus between two phases of menstrual cycle McNemar and Wilcoxon signed-rank tests were used, while intergroup analysis was performed by Chi-square and Mann-Whitney tests. The level of significance was assessed at $\mathrm{p}<0.05$.

\section{RESULTS}

Table 1 shows the frequency of pulp response to the applied stimuli. The reaction of the pulp to electrical stimulus was observed in all subjects and in all periods of measurement. On the other hand, the number of teeth

Table 1. Prevalence of dental pulp pain response on electrical and cold stimuli in regularly menstruating and postmenopausal women Tabela 1. Učestalost reakcije pulpe posle primene električnog i hladnog nadražaja kod žena sa redovnim menstrualnim ciklusom i žena u menopauzi

\begin{tabular}{|l|c|c|}
\hline $\begin{array}{l}\text { Group } \\
\text { Grupa }\end{array}$ & $\begin{array}{c}\text { Electrical test } \\
\text { Elektrotest } \\
\mathbf{n}(\%)\end{array}$ & $\begin{array}{c}\text { Cold test } \\
\text { Test } \mathbf{n a} \text { hladno } \\
\mathbf{n}(\%)\end{array}$ \\
\hline $\begin{array}{l}\text { Regularly menstruating women } \\
\text { Žene sa redovnim ciklusom }\end{array}$ & $20(100)$ & $20(100)$ \\
\hline $\begin{array}{c}\text { menstrual phase } \\
\text { menstrualna faza }\end{array}$ & $20(100)$ & $17(85)$ \\
\hline $\begin{array}{l}\text { luteal phase } \\
\text { lutealna faza }\end{array}$ & $20(100)$ & $13(65)^{*}$ \\
\hline $\begin{array}{l}\text { Postmenopausal women } \\
\text { Žene u menopauzi }\end{array}$ & \\
\hline
\end{tabular}

${ }^{*} p=0.008$ compared to menstrual phase in regularly menstruating women ${ }^{*} p=0,008$ u odnosu na menstrualnu fazu kod žena sa redovnim menstrualnim ciklusom 


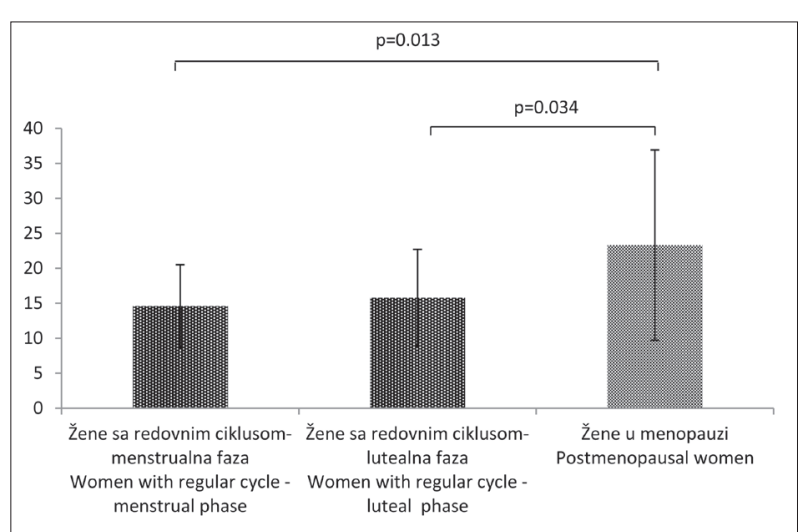

Graph 1. Mean ( \pm SD) of electrical pain threshold in premenopausal and postmenopausal women

Grafikon 1. Srednje vrednosti ( \pm SD) praga nadražaja pulpe na električni nadražaj kod žena sa redovnim menstrualnim ciklusom i žena u menopauzi

that were responsive to cold stimulation was lower in postmenopausal women (65\%) compared to women in menstrual $(100 \% ; \mathrm{p}=0.008)$ and luteal phase $(85 \%)$ of the cycle.

Mean values and standard deviations (SD) of stimulus threshold and intensity of pain in studied groups are shown in Graphs 1 and 2. The sensitivity analysis in the pulp with respect to the cycle phase showed greater pulp sensitivity to electrical (lower threshold level) and cold stimuli (higher pain intensity) in the menstrual compared to the luteal phase, however, the difference was statistically significant only for cold stimulation ( $\mathrm{p}=0.015)$. The pulp in postmenopausal women showed significantly higher threshold level to electric stimulus and significantly lower pain intensity to cold stimulus compared to women with regular menstrual cycle, regardless of the cycle phase (Graphs 1 and 2).

\section{DISCUSSION}

In order to clarify the possible influence of gonadal hormonal fluctuations on pain sensitivity of the pulp, the current research examined the effects of electric and cold stimuli in women of reproductive age, within two phases of menstrual cycle (menstrual and luteal), and postmenopausal women. The results showed that luteal phase in women with regular menstrual cycle characterized by high levels of gonadal hormones, and menopause - a period of chronic reduction in the level of gonadal hormones, are periods of lower pulp sensitivity.

In our study, pulpal pain was induced by electric and cold stimuli in healthy women without the presence of other painful conditions (experimental pain model). Evaluation of pain sensitivity in healthy subjects is important for investigation of various aspects of mechanisms that underlie pain. Sensory manifestations and sensory-motor interaction of previously clearly defined pain can be determined on experimental pain model. Moreover, experimental pain model is valuable for pharmacological and clinical studies in order to quantify the sensitivity of the nociceptive system in pain patients, as well as to predict

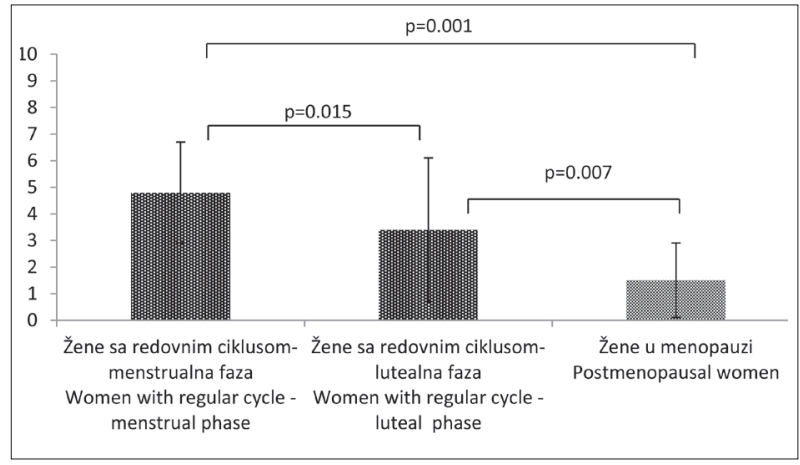

Graph 2. Mean $( \pm S D)$ of pain intensity to cold stimulation in premenopausal and postmenopausal women

Grafikon 2. Srednje vrednosti ( \pm SD) intenziteta pulpnog bola na hladni nadražaj kod žena sa redovnim menstrualnim ciklusom i žena u menopauzi

clinical pain and clinical pain outcomes [26]. Research on sensitivity of healthy women to various stimuli during menstrual cycle have not given clear evidence of experimental pain hormonal dependence [12,27]. Some authors have found that pain perception varies during the cycle $[15,16]$, while others have not confirmed a link between pain and hormonal fluctuations during the cycle $[17,18]$. Discrepancies in results can be attributed to methodological differences, such as type of observed experimental pain, stimulated tissue, a measuring outcomes (threshold or intensity) and functional division of the menstrual cycle with no measurement of gonadal hormone concentrations [12,27]. An interesting fact is that the brain cortex activity induced by experimental painful stimuli varies between menstrual phases with high levels of estrogen and phase characterized by low hormone levels, and these changes are not always accompanied by altered response to pain [28]. Unlike the experimental pain, it has been shown that pain in certain clinical pain conditions varies during menstrual cycle [10]. In these patients, many other factors can influence the perception of pain during menstrual cycle. Also, patients with pain conditions may have altered sensitivity to hormonal changes during the cycle.

The current study investigated the pulp reaction to electrical and cold stimuli. Electric pulp test and cold test using cold spray are the most frequently used tests for investigation of pulp sensitivity [29]. Various types of stimuli have been applied in experimental studies that investigate the relationship between hormonal status and pain and its characteristics. It has been observed that various stimuli differently activate nociceptive afferent fibres in the tissue. Electric stimuli trigger all classes of afferent neurons, while thermal stimuli only A- $\delta$ and $C$ fibres [30]. Also, certain types of stimuli can cause stress, while others activate endogenous regulatory mechanisms of pain. Therefore, hormonal status can have different effects on different stimuli. In fact, it has been shown that menstrual cycle has opposite effect on pain caused by electrical stimulus from pain caused by other painful stimuli (pressure, cold, warm, ischemic pain) [31]. In our study, higher pulp sensitivity to electrical as well as to cold stimulation was observed in the menstrual phase. Although various groups of nerve fibres contribute in the occurrence of various types of pain, in dentin-pulp complex both stimuli cause 
activation of peripherally placed $A-\delta$ fibres that are mediators of sharp, localized pain. Centrally positioned C fibres that are responsible for the appearance of dull, long-term pain were not activated during testing, unless greater intensity of electricity was applied or there was an irritation that caused tissue damage. It is important to note that in addition to the type of stimulation, pain sensitivity varies on the type of tested tissue and the depth of tissue to which the stimulus is applied [15].

In women of reproductive age increased pain sensitivity, especially to cold stimulation, was recorded during menstrual phase, phase characterized by low levels of estrogen and progesterone, while lower sensitivity was present during luteal phase when estrogen and progesterone levels were high. Gonadal hormones, estrogen and progesterone, can express pronociceptivne as well as antinociceptive effects depending on the overall hormonal profile [12]. It is believed that at the end of luteal and in early follicular phase, when the levels of both gonadal hormones are low, sympathetic tone, inflammatory response, the synthesis of prostaglandins and affective symptoms reach their highest level, while descending inhibitory systems are at the lowest level [12]. This explains why perimenstrual phase is period of increased sensitivity to various painful conditions. On the other hand, in the middle luteal phase, gonadal hormones reduce pain sensitivity through increased GABA-tic tone and increased cortisol secretion [12]. These mechanisms could explain differences in pulp sensitivity during investigated periods of menstrual cycle observed in the current study.

Compared with reproductive age women, in menopausal women sensitivity of pulp was lower, regardless of the applied stimulus and the phase of cycle. Although the influence of gonadal hormones in the reproductive age on clinical pain conditions is somewhat clarified, data on their impact in menopause are different [27]. A study that compared the incidence of various painful conditions in menopausal women with premenopausal period, has found that menopausal changes depend on the type and characteristics of pain [14]. Headaches and cervical / lumbar pain decreased or even disappeared, while developed or intensified joint pain affected more than half of women. Pain intensity and painful area also change with menopause. In most of the cases, high intensity pain that would affect larger area remained unchanged or decreased, while low intensity pain and pain that affects smaller less area increased [14]. The impact of ageing process on the pulp tissue and its sensitivity should not be ignored. Reduction of painful pulp reactions in elderly is attributed to reduction in number of nerve fibres, creation of secondary and tertiary dentin and tubule occlusion [32]. However, significant impact of age on dental pulp response caused by electrical stimulation was not found $[33,34]$. Reaction to electrical test was obtained in all subjects, in women of reproductive age as well as menopausal women. On the other hand, it has been shown that the sensitivity of pulp to cold stimuli decreases with age [35]. Unlike electrical test, which is dependent on the ions movement, cold stimulus causes pain response by dentinal fluid movement [36], which can partly ex- plain reduction of pulp sensitivity to cold in menopausal women. In the current study response to cold stimulation was not obtained in $35 \%$ of menopausal women even after two repeated measurements. An interesting finding is that the application of cold spray caused a painful reaction in all subjects in the menstrual phase, but not in $15 \%$ of subjects in the luteal phase, what could be misinterpreted in clinical conditions as a loss of tooth vitality. Studies have shown that the response of dental pulp to cold stimulation is the most reliable in this particular age group (21-50 years) [29]. Findings of decreased pain sensitivity in the luteal phase of menstrual cycle characterized by high levels of sex hormones, as well as reduced sensitivity during menopause, a period of chronic reduction in the levels of gonadal hormones, suggest that if there is an association between gonadal hormone levels and pain sensitivity, it is not simple.

Potential variations were not examined in this study. Namely, the division of menstrual cycle in phases was performed on the basis of medical history, without measurement of gonadal hormone concentration. Measuring gonadal hormones levels is important for precise determination of menstrual cycle phase, as well as in determining the correlation between hormonal levels and painful response. However, only a few studies have investigated the influence of gonadal hormone concentration on experimental pain until now. Secondly, sensitivity of the pulp is measured only in the two phases of menstrual cycle. However, to determine the relationship between hormonal status and pain, a research should include more cycle phases.

\section{CONCLUSION}

The results of this pilot study indicate correlation between pulpal pain and menstrual cycle. Higher sensitivity of the pulp to cold stimulus was recorded in the menstrual phase compared to the luteal phase. Pulpal sensitivity in menopausal women was reduced regardless of the type of stimulus and cycle phase.

\section{REFERENCES}

1. Unruh AM. Gender variations in clinical pain experience. Pain. 1996; 65(2-3):123-67. [PMID: 8826503]

2. Riley JL 3rd, Robinson ME, Wise EA, Myers CD, Fillingim RB. Sex differences in the perception of noxious experimental stimuli: a metaanalysis. Pain. 1998; 74(2-3):181-7. [PMID: 9520232]

3. Dworkin SF, Huggins KH, LeResche L, Von Korff M, Howard J, Truelove E, et al. Epidemiology of signs and symptoms in temporomandibular disorders: Clinical signs in cases and controls. J Am Dent Assoc. 1990; 120(3):273-81. [DOI: 10.14219/jada.archive.1990.0043] [PMID: 2312947]

4. Verbrugge LM, Gates DM, Ike RW. Risk factors for disability among U.S. adults with arthritis. J Clin Epidemiol. 1991; 44(2):167-82. [DOI: 10.1016/0895-4356(91)90264-A] [PMID: 1825325]

5. Wolfe F, Ross K, Anderson ), Russell IJ, Hebert L. The prevalence and characteristics of fibromyalgia in the general population. Arthritis Rheum. 1995; 38(1):19-28. [DOI: 10.1002/art.1780380104] [PMID: 7818567] 
6. Schwartz BS, Stewart WF, Simon D, Lipton RB. Epidemiology of tension-type headache. JAMA. 1998; 279(5):381-3.

[DOI: 10.1001/jama.279.5.381] [PMID: 9459472]

7. Symmons D, Turner G, Webb R, Asten P, Barrett E, Lunt M, et al. The prevalence of rheumatoid arthritis in the United Kingdom: New estimates for a new century. Rheumatology (Oxford). 2002; 41:793800. [DOI: 10.1093/rheumatology/41.7.793] [PMID: 12096230]

8. Mayer EA, Berman S, Chang L, Naliboff BD. Sex based differences in gastrointestinal pain. Eur J Pain. 2004; 8(5):451-63. [DOI: 10.1016/j.ejpain.2004.01.006] [PMID: 15324776]

9. Frot M, Feine JS, Bushnell MC. Sex differences in pain perception and anxiety. A psychophysical study with topical capsaicin. Pain. 2004; 108(3):230-6. [DOI: 10.1016/j.pain.2003.11.017] [PMID: 15030942]

10. Craft RM. Modulation of pain by estrogens. Pain. 2007; 132 Suppl 1:S3-12. [DOI: 10.1016/j.pain.2007.09.028] [PMID: 17951003]

11. LeResche L, Mand L, Sherman JJ, Gandara B, Dworkin SF. Changes in temporomandibular pain and other symptoms across the menstrual cycle. Pain. 2003; 106(3):253-61. [DOI: 10.1016/j.pain.2003.06.001] [PMID: 14659508]

12. Martin TV. Ovarian hormones and pain response: a review of clinical and basic science studies. Gend Med. 2009; 6 Suppl 2:168-92. [DOl: 10.1016/j.genm.2009.03.006] [PMID: 19406368]

13. Pamuk ON, Cakir N. The variation in chronic widespread pain and other symptoms in fibromyalgia patients. The effects of menses and menopause. Clin Exp Rheumatol. 2005; 23(6):778-82. [PMID: 16396694]

14. Meriggiola MC, Nanni M, Bachiocco V, Vodo S, Aloisi AM. Menopause affects pain depending on pain type and characteristics. Menopause. 2012; 19(5):517-23. [DOI: 10.1097/gme.0b013e318240fe3d] [PMID: 22334057]

15. Giamberardino MA, Berkley KJ, lezzi S, de Bigontina P, Vecchiet L. Pain threshold variations in somatic wall tissues as a function of menstrual cycle, segmental site and tissue depth in non-dysmenorrheic women, dysmenorrheic women and men. Pain. 1997; 71(2):187-97. [PMID: 9211480]

16. Cimino R, Farella M, Michelotti A, Pugliese R, Martina R. Does the ovarian cycle influence the pressure-pain threshold of the masticatory muscles in symptom-free women? J Orofac Pain. 2000; 14(2):105-11. [PMID: 11203744]

17. Bartley EJ, Rhudy JL. Comparing pain sensitivity and the nociceptive flexion reflex threshold across the mid-follicular and late-luteal menstrual phases in healthy women. Clin J Pain. 2013; 29(2):154-61. [DOI: 10.1097/AJP.0b013e31824c5edb] [PMID: 22688607]

18. Bartley EJ, Palit S, Kuhn BL, Kerr KL, Terry EL, DelVentura JL, et al. Natural variation in testosterone is associated with hypoalgesia in healthy women. Clin J Pain. 2015; 31(8):730-9. [DOI: 10.1097/AJP.0000000000000153] [PMID: 25185874]

19. Fields HL, Basbaum Al. Central nervous system mechanisms of pain modulation. In Wall and Melzack's Textbook of Pain. S.B. MacMahon, M. Koltzenburg, eds. (London: Churchill Livingstone); 2005; pp. 125-42.

20. Deroo BJ, Korach KS. Estrogen receptors and human disease. J Clin Invest. 2006; 116(3):561-70. [DOI: 10.1172/JCI27987] [PMID: 16511588]

21. Roglio I, Bianchi R, Gotti S, Scurati S, Giatti S, Pesaresi M, et al. Neuroprotective effects of dihydroprogesterone and progesterone in an experimental model of nerve crush injury. Neuroscience. 2008;
155(3):673-85. [DOI: 10.1016/j.neuroscience.2008.06.034] [PMID: 18625290]

22. Kuba T, Wu HB, Nazarian A, Festa ED, Barr GA, Jenab S, et al. Estradiol and progesterone differentially regulate formalininduced nociception in ovariectomized female rats. Horm Behav. 2006; 49(4):441-9. [DOI: 10.1016/j.yhbeh.2005.09.007] [PMID: 16257405]

23. Jukić S, Prpić-Mehicić G, Talan-Hranilovć J, Miletić I, Segović S, Anić I. Estrogen receptors in human pulp tissue. Oral Surg Oral Med Oral Pathol Oral Radiol Endod. 2003; 95(3):340-4. [DOl: 10.1067/moe.2003.9] [PMID: 12627107]

24. Dzeletovic B, Grga D, Krsljak E, Stratimirovic D, Brkovic B, Stojic D. Dental pulp blood flow and its oscillations in women with different estrogen status. J Endod. 2012; 38(9):1187-91.

[DOI: 10.1016/j.joen.2012.06.009] [PMID: 22892733]

25. Tófoli GR, Ramacciato JC, Volpato MC, Meechan JG, Ranali J, Groppo FC. Anesthetic efficacy and pain induced by dental anesthesia: the influence of gender and menstrual cycle. Oral Surg Oral Med Oral Pathol Oral Radiol Endod. 2007; 103(2):e34-8.

[DOI: 10.1016/j.tripleo.2006.08.024] [PMID: 17095263]

26. Arendt-Nielsen L, Graven-Nielsen T. Muscle pain: sensory implications and interaction with motor control. Clin J Pain. 2008; 24(4):2918. [DOl: 10.1097/AJP.0b013e31815b608f] [PMID: 18427227]

27. lacovides S, Avidon I, Baker FC. Does pain vary across the menstrual cycle? A review. Eur J Pain. 2015; 19(10):1389-405.

[DOI: 10.1002/ejp.714] [PMID: 25899177]

28. Veldhuijzen DS, Keaser ML, Traub DS, Zhuo J, Gullapalli RP, Greenspan JD. The role of circulating sex hormones in menstrual cycledependent modulation of pain-related brain activation. Pain. 2013; 154(4):548-59. [DOI: 10.1016/j.pain.2012.12.019] [PMID: 23528204]

29. Jespersen JJ, Hellstein J, Williamson A, Johnson WT, Qian F. Evaluation of dental pulp sensibility tests in a clinical setting. J Endod. 2014; 40(3):351-4. [DOI: 10.1016/j.joen.2013.11.009] [PMID: 24565651]

30. Keefe FJ, Fillingim RB, Williams DA. Behavioral assessment of pain: nonverbal measures in animals and humans. Inst Lab Animal Res News. 1991; 33:3-13.

31. Riley JL 3rd, Robinson ME, Wise EA, Price DD. A meta-analytic review of pain perception across the menstrual cycle. Pain. 1999; 81(3):22535. [PMID: 10431710]

32. Bernick S, Nedelman C. Effect of aging on the human pulp. J Endod. 1975; 1(3):88-94. [DOI: 10.1016/S0099-2399(75)80024-0] [PMID: 1061788]

33. Harkins SW, Chapman CR. The perception of induced dental pain in young and elderly women. J Gerontol. 1977; 32(4):428-35. [DOI: 10.1093/geronj/32.4.428] [PMID: 864207]

34. da Silva LA, Lin SM, Teixeira MJ, de Siqueira JT, Jacob Filho W, de Siqueira S. Sensorial differences according to sex and ages. Oral Dis. 2014; 20(3):e103-10. [DOI: 10.1111/odi.12145] [PMID: 23796393]

35. Farac RV, Morgental RD, Lima RK, Tiberio D, dos Santos MT. Pulp sensibility test in elderly patients. Gerodontology. 2012; 29(2):135-9. [DOI: 10.1111/j.1741-2358.2012.00623.x] [PMID: 22612824]

36. Bender IB. Pulpal pain diagnosis-a review. J Endod. 2000; 26(3):175-9. [DOI: 10.1097/00004770-200003000-00012] [PMID: 11199715]

Received: 24.06.2016 • Accepted: 31.08 .2016 


\title{
Pulpni bol kod žena u reproduktivnoj dobi i menopauzi: pilot studija
}

\author{
Jelena Krunić', Irena Mladenović2 ${ }^{2}$ Nikola Stojanović ${ }^{1}$ \\ 'Univerzitet u Istočnom Sarajevu, Medicinski fakultet, Katedra za bolesti zuba i endodonciju, Foča, Republika Srpska, Bosna i Hercegovina; \\ ¿Univerzitet u Istočnom Sarajevu, Medicinski fakultet, Katedra za oralnu rehabilitaciju, Foča, Republika Srpska, Bosna i Hercegovina
}

\begin{abstract}
KRATAK SADRŽAJ
Uvod Cilj ovog pilot istraživanja je bio da se ispita pulpni bol izazvan delovanjem električnog i hladnog nadražaja u različitim fazama menstrualnog ciklusa kod zdravih žena sa redovnim menstrualnim cikusom i da se uporedi sa pulpnim bolom žena u menopauzi. Materijal i metode rada $U$ istraživanje je uključeno 20 zdravih žena sa redovnim menstrualnim ciklusom i 20 zdravih žena u menopauzi. Osetljivost pulpe donjeg centralnog sekutića je određena primenom električnog i hladnog nadražaja. Ispitanice sa redovnim menstrualnim ciklusom su ispitane u toku menstrualne i lutealne faze ciklusa, a žene u menopauzi jednom. Rezultati su prikazani kao prag nadražaja za električni, odnosno intenzitet bola za test na hladno.

Rezultati Veći prag nadražaja $(p=0,484)$ i manji intenzitet bola $(p=0,015)$ zabeležen je u lutealnoj u poređenju sa menstrualnom fazom kod žena sa redovnim menstrualnim ciklusom. Kod žena u menopauzi prag nadražaja je značajno veći i intenzitet bola značajno manji u poređenju sa ženama u repoduktivnoj dobi, nezavisno od faze ciklusa i vrste primljenog stimulansa.

Zaključak Manja osetljivost pulpe je zabeležena kod žena u lutealnoj fazi ciklusa, kao i kod žena u periodu menopauze.

Ključne reči: bol; menopauza; menstrualni ciklus; zubna pulpa
\end{abstract}

\section{UVOD}

Brojna klinička i eksperimentalna istraživanja o povezanosti pola i različitih bolnih stanja su ukazala na njihovu češću pojavu kod žena [1,2]. Migrenozne i tenzione glavobolje, fibromialgija, reumatoidni artritis, artritis, sindrom iritibilnog kolona i temporomandibularne disfunkcije (TMD) češće se javljaju kod žena u poređenju sa muškarcima [1,3-8]. Takođe, kod žena bolovi su jači, učestaliji i dugotrajniji $[1,9]$. U odnosu na muškarce, žene se značajno češće javljaju i na terapiju različitih bolnih stanja [1]. Polne razlike u percepciji i u odgovoru na bol se mogu pripisati socijalnim, neurofiziološkim, genetskim i imunološkim uticajima, kao i delovanju polnih hormona. Veliki broj nalaza ukazuje na povezanost polnih hormona i bola kod žena $[1,10]$. U toku života, značajne promene u kliničkim bolnim stanjima žene su modulirane hormonalnim statusom. Naime, TMD i migrenozne glavobolje se najčešće javljaju posle puberteta, sa najvećom učestalošću između 20. i 45. godine života, odnosno u reproduktivnoj dobi [10]. Bol kod TMD, migrenozni bol, ali i bol kod drugih bolnih stanja se pojačava neposredno pred kraj menstrualnog ciklusa i tokom prvih dana menstruacije $[11,12]$. Ovi nalazi ukazuju da snižavanje nivoa estrogena i progesterona tokom perimenstrualne faze izaziva bol, odnosno intenzivira ga. Hormonski milje tokom rane lutealne faze (sniženje nivoa koncentracije estrogena i povećanje nivoa progesterona) takođe se povezuje sa povećanom učestalošću migrenoznih bolova [12]. Slično, bol kod TMD se može ponovo intenzivirati u toku perioda ovulacije, faze brze izmene nivoa estrogena [11]. Sa druge strane, fluktuacije bola tokom menstrualnog ciklusa kod pacijenata sa fibromialgijom nisu zabeležene [12].

Promene u bolnim stanjima se mogu očekivati i posle završetka reproduktivnog doba, kako zbog fiziološkog procesa starenja tako i zbog drugih medicinskih razloga. Istraživanja pokazuju da se učestalost TMD i migrenoznih glavobolja smanjuje posle menopauze [10], ali se povećava učestalost drugih bolnih sindroma kao što su fibromialgija i artritis [10,13]. Ovi nalazi ukazuju da izmene bolnih stanja posle menopauze zavise od vrste i karakteristika bola [14].
Za razliku od kliničkih bolnih stanja, još uvek nije jasno da li je bolna osetljvost na različite akutne nadražaje kod zdravih žena (eksperimentalni bol) zavisna od hormonalnog statusa. Naime, pojedini autori ukazuju na povećanu osetljivost zdravih žena na nadražaje tokom različitih faza menstrualnog ciklusa $[15,16]$, dok drugi na odsustvo varijabilnosti u odgovoru na bol tokom ciklusa $[17,18]$. Modulacija bola se odvija na više nivoa: primarnim aferentnim vlaknima, kičmenoj moždini, moždanom stablu i mozgu [19]. Receptori za polne horomone se nalaze u nervnom sistemu [20], što ukazuje na mogući uticaj horomona na različite strukture nervnog sistema. Istraživanja su dokazala da polni hormoni interaguju sa nociceptivnim procesom na više nivoa i u perifernom i centralnom nervnom sistemu [12,21]. Ipak, uloga polnih hormona u nociceptivnoj modulaciji je kompleksna i još uvek nije u potpunosti razjašnjena [22].

Varijacije polnih hormona tokom menstrualnog ciklusa i u različitim periodima života bi mogle da utiču na fiziološke i patološke odgovore zubne pulpe. Naime, dokazano je prisustvo estrogenskih receptora u tkivu pulpe žena u reproduktivnoj dobi, kao i u pulpi žena u menopauzi, koje nije zavisno od starosne dobi [23]. Takođe, pokazano je da je snižen nivo estrogena u menstrualnoj fazi kod žena sa redovnim ciklusom i kod žena u menopauzi povezan sa smanjenim protokom krvi u tkivu pulpe [24]. Međutim, u istraživanju Tófoli i sar. [25], gde je ispitivana povezanost između anestetičke efikasnosti i bola prilikom aplikacije lokalne anestezije sa menstrualnim ciklusom, nije uočen značajan uticaj ciklusa na ispitivane parametre lokalne anetsezije kod zdravih žena sa redovnim menstrualnim ciklusom i onih koje uzimaju oralne kontraceptive. Uticaj hormonalnih promena tokom menstrualnog ciklusa i u periodu menopauze na pulpnu bol još uvek nije ispitivan. Poznavanje ovih interakcija bi moglo biti od velike važnosti za efikasnije lečenje pacijenata.

Cilj ovog pilot istraživanja je da se ispita pulpni bol izazvan delovanjem električnog i hladnog nadražaja u različitim fazama menstrualnog ciklusa kod zdravih žena sa redovnim cikusom i da se uporedi sa pulpnim bolom žena u menopauzi. 


\section{MATERIJAL I METODE RADA}

Ispitivanjem je obuhvaćeno 40 žena koje su se javile u Specijalistički centar Medicinskog fakulteta Univerziteta u Istočnom Sarajevu, Republika Srpska, Bosna i Hercegovina, radi kontrolnog pregleda ili kao pratnja osobama sa zakazanom stomatološkom intervencijom. Ispitanice su podeljene u dve grupe: grupu žena sa redovnim menstrualnim ciklusom (trajanje menstrualnog ciklusa između 26 i 28 dana), starosti od 20 do 40 godina (prosečna starost $32,8 \pm 5,9)(\mathrm{n}=20)$ i grupu žena u menopauzi (najmanje dve godine od početka menopauze) starosti od 50 do 65 godina (prosečna starost 59,6 $\pm 4,4)(n=20)$. Kriterijumi za uključivanje u studiju su bili: postojanje klinički intaktnog donjeg centralnog sekutića (bez karijesa, restauracija, fiksne nadoknade i bez znakova zubnog trošenja) bez znakova i simptoma znakova oštećenja pulpe i apeksnog periodoncijuma. Žene sa sistemskim oboljenjima, žene u toku trudnoće, one koje se nalaze na hormonskoj ili drugoj terapiji ili koje su uzimale lekove koji utiču na percepciju bola $24 \mathrm{~h}$ pre ispitivanja nisu uključene $u$ istraživanje. $U$ istraživanje nisu uključene ni one ispitanice kod kojih je neposredno pre početka istraživanja završena ortodontska ili parodontološka terapija ili je zabeleženo traumatsko oštećenje zuba. Od svake ispitanice u istraživanje je uključen samo jedan zub.

Ispitanice sa redovnim menstrualnim ciklusom su ispitane dva puta: u toku menstrualne (1-5. dan ciklusa) i lutealne faze (17-23. dan ciklusa) menstrualnog ciklusa, a žene u menopauzi jednom. Osetljivosti pulpe je ispitana na električni i hladni stimulans. Pre ispitivanja zub je izolovan vaterolnama i posušen. $\mathrm{Za}$ ispitivanje osetljivosti na električni nadražaj primenjen je aparat za ispitivanje vitaliteta (Analytical Technologies, Redmond, WA) sa skalom od 0 do 80 . Da bi se obezbedio intimniji kontakt elektrode aparata sa površinom zuba, na vrh elektrode je postavljena manja količina paste za zube. Elektroda aparata je postavljena na incizalnu trećinu vestibularne površine zuba. Ispitanice su zamoljene da podizanjem ruke signaliziraju kada prvi put osete bol. Najmanji intenzitet struje na kome je dobijena reakcija pulpe predstavljao je prag nadražaja. Osetljivost pulpe na hladno je određena primenom hladnog spreja (EndoFrost $-50^{\circ} \mathrm{C}$; Coltene/Whaledent, Altstatten, Switzerland), koji je na incizalnu ivicu zuba aplikovan preko vatice i pincete $u$ trajanju od 15 sekundi, odnosno dok ispitanice nisu signalizirale pulpnu reakciju. Ispitanice su zamoljene da odrede intenzitet doživljenog nadražaja (intenzitet bola) na numeričkoj vizuelnoj skali bola, gde vrednost 0 predstavlja odsustvo bola, dok vrednost 10 predstavlja najveći bol koji je ikada doživljen. Vrednost 0 je određena u onim situacijama gde nije zabeležen odgovor pulpe posle ponovljene primene nadražaja, sa pauzom od dva minuta između dva merenja.

Statistička analiza podataka je urađena u statističkom programu SPSS 19.0 (SPSS, IBM Corp., Armonk, NY). Rezultati su prikazani u obliku srednjih vrednosti i standardnih devijacija (SD) za numerička, odnosno učestalosti za atributivna obeležja. Za određivanje razlike u reakciji pulpe na električni nadražaj u različitim fazama menstrualnog ciklusa kao i između grupa korišćen je t-test za vezani uzorak, donosno t-test za dva nezavisna uzorka. Razlike u učestalosti reakcije i intenzitetu bola na hladni nadražaj između dve faze ciklusa su ispitane primenom Mek Nemarovog testa i Vilkoksonovog testa ekvivalentnih parova, a između ispitivanih grupa korišćenjem hi-kvadrat i Man-Vit- nijevog testa. Vrednosti $\mathrm{p}<0,05$ su smatrane značajnim u svim analizama.

\section{REZULTATI}

U tabeli 1 prikazana je učestalost reakcije pulpe na primenjene stimulanse. Reakcija pulpe na elektrotest je zabeležena kod svih ispitanica i u svim periodima merenja. Sa druge strane, broj zuba koji su reagovali na hladni nadražaj je bio manji kod žena u menopauzi (65\%) u poređenju sa ženama u menstrualnoj fazi $(100 \% ; \mathrm{p}=0,008)$ i lutealnoj fazi (85\%) ciklusa.

Srednje vrednosti i standardne devijacije (SD) praga nadražaja i intenziteta bola u ispitivanim grupama su prikazane na grafikonima 1 i 2 . Analiza osetljivosti pulpe u zavisnosti od faze ciklusa pokazuje veću osetljivost pulpe na električni (niži prag nadražaja) i hladni stimulans (veći intenzitet bola) u menstrualnoj u poređenju sa lutealnom fazom, ali razlika je dostigla statističku značajnost samo za nadražaj na hladno $(\mathrm{p}=0,015)$. Pulpa kod žena u menopauzi je pokazala značajno veći prag nadražaja na električni stimulans i značajno manji intenzitet bola na hladno u poređenju sa ženama sa redovnim menstrualnim ciklusom, bez obzira na fazu ciklusa (Grafikon 1 i 2).

\section{DISKUSIJA}

Kako bi se razjasnio mogući uticaj fluktuacije polnih hormona na bolnu osetljivost pulpe, u okviru ovog istraživanja je ispitivan efekat električnog i hladnog stimulansa kod žena u reproduktivnoj dobi, u okviru dve faze menstrualnog ciklusa (menstrualne i lutealne), i kod žena u menopauzi. Dobijeni rezultati su pokazali da lutealna faza kod žena sa redovnim menstrualnim ciklusom, koju karakteriše visok nivo polnih hormona, i menopauza, period hroničnog smanjenja nivoa polnih hormona, jesu periodi manje osetljivosti pulpe.

U ovom istraživanju pulpni bol je izazvan delovanjem električnog i hladnog stimulansa kod zdravih žena bez prisutnih drugih bolnih stanja (model eksperimentalnog bola). Određivanje bolne osetljivosti zdravih ispitanika je od važnosti za ispitivanje različitih aspekata mehanizama koji se nalaze u osnovi bola. Na eksperimentalnom modelu bola se mogu odrediti senzorne manifestacije i senzorno-motorne interakcije prethodno jasno definisanog bola. Takođe, eksperimentalni model bola je od važnosti u farmakološkim i kliničkim istraživanjima da bi se odredila osetljivost nociceptivnog sistema kod pacijenata sa bolom, kao i u cilju predviđanja nastanka kliničkih bolnih stanja i njihovih posledica [26]. Istraživanja o osetljvosti zdravih žena na različite nadražaje tokom menstrualnog ciklusa nisu dala jasne dokaze o hormonalnoj zavisnosti eksperimentalnog bola $[12,27]$. Pojedini autori nalaze da percepcija bola varira tokom ciklusa $[15,16]$, dok drugi ne potvrđuju povezanost bola i hormonskih fluktuacija tokom ciklusa $[17,18]$. Neslaganja u rezultatima se većim delom mogu pripisati metodološkim razlikama kao što su vrsta eksperimentalnog bola koji se ispituje, tkivo koje se stimuliše, način merenja bola (prag ili intenzitet) i funkcionalna podela menstrualnog ciklusa bez kvantifikacije nivoa hormona [12,27]. Interesantan je podatak da se aktivnost korteksa mozga na eksperimentalni bolni stimulans razlikuje između menstrualne faze sa visokim nivoom estrogena i faze 
koju karakteriše nizak nivo hormona, i da te promene nisu uvek praćene promenjenim odgovorom na bol [28]. Za razliku od eksperimentalnog bola, dokazano je da bol kod određenih kliničkih bolnih stanja varira tokom menstrualnog ciklusa [10]. Kod ovih pacijenata brojni drugi faktori mogu da utiču na percepciju bola tokom menstrualnog ciklusa. Takođe, pacijenti sa bolnim stanjima mogu imati izmenjenu osetljivost na hormonalne promene tokom ciklusa.

U ovom istraživanju je ispitivana reakcija pulpe na električnu i hladnu stimulaciju. Elektrotest i test na hladno, primenom hladnog spreja, najčešće su primenjivani testovi za ispitivanje osetljivosti pulpe [29]. Različte vrste stimulansa se primjenjuju u eksperimentalnim istraživanjima koja istražuju povezanost hormonalnog statusa sa bolom i njegovim karakteristikama. Uočeno je da različiti nadražaji različito aktiviraju aferentna nociceptivna vlakna u tkivima. Električni aktiviraju sve klase aferentnih neurona, a termalni stimulansi samo A- $\delta$ i $C$ vlakna [30]. Takođe, pojedine vrste nadražaja mogu izazvati stres, dok druge aktiviraju endogene regulatorne mehanizme bola. Stoga, hormonalni status može imati različite efekte na različite stimulanse. Naime, pokazano da menstrualni ciklus ima suprotan efekat na električnim nadražajem izazvanim bolom od bola koji izazivaju drugi bolni stimulansi (pritisak, hladno, toplo i ishemični bolni stimulansi) [31]. U ovom istraživanju veća osetljivost pulpe i na električnu i na hladnu stimulaciju je uočena u menstrualnoj fazi. Iako različite grupe nervnih vlakana doprinose nastanku različitih vrsta bola, oba stimulansa u pulpo-dentinskom kompleksu izazivaju aktivaciju perifeno postavljenih A- $\delta$ vlakana, koja su medijatori oštrog, lokalizovanog bola. Centralno pozicionirana $C$ vlakna, koja su odgovorna za pojavu tupog, dugotrajnog bola, ne aktiviraju se prilikom testiranja, osim ukoliko se ne primeni struja većeg intenziteta, odnosno nadražaj koji uzrokuje oštećenja tkiva. Važno je pomenuti da pored vrste nadražaja, bolna osetljvost varira $u$ zavisnosti od vrste tkiva koje se ispituje i dubine tkiva na koje se stimulans primenjuje [15].

Kod žena u reproduktivnoj dobi veća bolna osetljivost, posebno na hladnu stimulaciju, zabeležena je tokom menstrualne faze, faze koju karakteriše nizak nivo estrogena i progesterona, dok je niža osetljivost bila prisutna tokom lutealne faze, kada su koncentracije estrogena i progesterona visoke. Polni hormoni, estrogen i progesteron, mogu da ispolje i pronociceptivne i antinociceptivne efekte, što zavisi od celokupnog hormonskog profila [12]. Smatra se da na kraju lutealne i u ranoj folikularnoj fazi, kada su nivoi oba polna hormona niski, simpatički tonus, inflamatorni odgovor, sinteza prostaglandina i afektivni simptomi dostižu svoj najveći nivo, dok su descendentni inhibitorni sistemi na najnižem nivou [12]. Ovim se objašnjava zašto je perimenstrualna faza vreme povećane osetljivosti za različita bolna stanja. Sa druge strane, u sredini lutealne faze, polni horomoni smanjuju bolnu osetljivost zbog povećanja GABAneričkog tonusa i pojačanog oslobađanja kortizola [12]. Ovim mehanizmima bi se mogle objasniti razlike u osetljivosti pulpe $\mathrm{u}$ ispitivanim fazama menstrualnog ciklusa uočene u ovom istraživanju.

U poređenju sa ženama u reproduktivnoj dobi, kod žena u menopauzi osetljivost pulpe je niža, nezavisno od primenjenog stimulansa i faze ciklusa. Iako je uticaj polnih hormona u reproduktivnoj dobi na klinička bolna stanja donekle razjašnjen, podaci o njihovom uticaju u menopauzi su različiti [27]. U istraživanju u kojem je komparirana učestalost različitih bolnih stanja u menopauzi sa periodom pre menopauze, uočeno je da promene koje nastaju u menopauzi zavise od vrste i karateristika bola [14]. Naime, glavobolje i cervikalni/lumbalni bolovi su se smanjili ili čak nestali, dok je došlo do razvoja ili pojačavanja bola u zglobovima u više od polovine žena. Intenzitet i bolno područje se takođe menjaju sa menopauzom. U većini slučajeva bolovi visokog intenziteta koji su zahvatali veću površinu ostajali su nepromenjeni ili su se smanjili, dok su se bolovi slabog intenziteta i oni koji su zahvatali manje područje pogoršali [14]. Ne treba zanemariti uticaj samog procesa starenja na tkivo pulpe i njenu osetljivost. Smanjenje bolnih reakcija pulpe kod starijih osoba se pripisuje redukciji broja nervnih vlakana, stvaranju sekundarnog i tercijarnog dentina, kao i okluziji tubula [32]. Ipak, nije pokazan značajan uticaj godina na reakciju zubne pulpe izazvane električnom stimulacijom $[33,34]$. Elektrotestom reakcija je dobijena kod svih ispitanica, i žena u reproduktivnoj dobi i žena u menopauzi. Sa druge strane, pokazano je da se osetljivost pulpe na hladno smanjuje sa starenjem [35]. Za razliku od elektrotesta, koji je zavisan od kretanja jona, hladni stimulans izaziva bolnu reakciju kretanjem dentinskog likvora [36], čime se delimično može objasniti smanjenje osetljivosti pulpe na hladno kod žena u menopauzi. Naime, u ovoj studiji kod čak 35\% žena u menopauzi nije dobijena reakcija na hladnu stimulaciju ni posle dva ponovljena merenja. Interesantan nalaz je da je primena hladnog spreja izazvala bolnu reakciju kod svih ispitanica u menstrualnoj, ali ne i kod 15\% njih u lutealnoj fazi, što bi se u kliničkim uslovima moglo pogrešno interpretirati kao gubitak vitaliteta zuba. Istraživanja pokazuju da je reakcija zubne pulpe na hladnu stimulaciju najpouzdanija baš u ovoj starosnoj dobi (21-50) godina [29]. Uzimajući u obzir postojanje smanjene bolne osetljivosti u lutealnoj fazi menstrualnog ciklusa, koju karakteriše visok nivo polnih hormona, kao i smanjenu bolnu osetljivost tokom menopauze, perioda hroničnog smanjenja nivoa polnih hormona, može se pretpostaviti da ako uticaj polnih hormona na bolnu osetljivost i postoji, taj uticaj nije jednostavno linearan.

Veliki broj potencijalnih varijabli nije ispitan u ovom istraživanju. Naime, podela menstrualnog ciklusa na faze je sprovedena na osnovu anamnestičkih podataka, bez kvantifikacije polnih hormona. Merenje nivoa polnih hormona je od značaja, kako zbog preciznog određivanja faze menstrualnog ciklusa, tako i za određivanje korelacije između nivoa horomana i bolnog odgovora. Ipak, samo u nekoliko studija do sada je ispitivan uticaj koncentracije polnih hormona na eksperimentalni bol. Takođe, osetljivost pulpe je merena samo u dve faze menstrualnog ciklusa. Ipak, za utvrđivanje povezanosti hormonalnog statusa sa bolom ispitivanje treba da obuhvati veći broj ciklusnih faza.

\section{ZAKLJUČAK}

Rezultati ove pilot studije ukazuju na povezanost između pulpnog bola i menstrualnog ciklusa. Veća osetljivost pulpe na hladni stimulans je zabeležena u menstrualnoj fazi u poređenju sa lutealnom fazom. U odnosu na žene u reproduktivnoj dobi, osetljivost pulpe kod žena u menopauzi je smanjena, nezavisno od vrste nadražaja i faze ciklusa. 